\title{
Jędrzej Fostiak*
}

\section{SZKOCCY NACJONALIŚCI I KWESTIA SECESJI OD WIELKIEJ BRYTANII}

\section{Wprowadzenie}

W artykule nie będę przedstawiał całego problemu definicji oraz szczegółowych dociekań dotyczących nacjonalizmu, ponieważ z racji złożoności tego tematu oraz specyfiki zagadnienia nie byłoby to możliwe. Należy się jednak krótkie wprowadzenie i przytoczenie definicji najważniejszych autorów oraz twórców definicji pojęcia. Moim celem jest przedstawienie charakterystyki Szkockiej Partii Narodowej oraz wyjątkowości jej postulatów, jakimi się kierowała w swoim dążeniu do uniezależnienia się od Korony Brytyjskiej oraz wyników referendum niepodległościowego. Determinacja i wytrwałość godna pochwały i naśladowania, z jaką od ponad 60 lat, krok po kroku, realizowali cel, jaki sobie postawili, który do chwili głosowania nabrał realnego kształtu i mógł umożliwić spełnienie snu o niepodległości, o jakim prawdopodobnie nie marzyli sami twórcy i założyciele partii, snu - ponad trzystuletniego - o niepodległości.

\section{Nacjonalizm w skrócie}

Nacjonalizm jest pojęciem bardzo szerokim i nie do końca zdefiniowanym - istnieje wiele jego rodzajów i odmian. Termin nacjonalizm wywodzi się ze starego pojęcia „naród” i stanowi stosunkowo nowe pojęcie w nomenklaturze oraz literaturze naukowej. Początki analizy nacjonalizmu szacuje się na koniec XIX

* Jędrzej Fostiak, doktorant w Instytucie Politologii i Europeistyki Uniwersytetu Szczecińskiego, e-mail: fostiak@interia.eu. 
i drugą dekadę XX wieku, kiedy to znani psychologowie zajęli się tym zjawiskiem, m.in. Gustaw Le Bon, Ernest Barker, Partridge, Walter Bowers Pillsbury, William McDougall (przedstawiciele powstałej we Francji psychologii społecznej). Kolejny etap naukowego rozwoju nacjonalizmu, a właściwie jego analizy, nastąpił w okresie międzywojennym, gdy tematykę podjęli historycy, m.in. Carlton Hayes i Hans Kohn (po II wojnie światowej), którzy jako pierwsi prowadzili nieustanną próbę, bezstronnej analizy ideologii i mimo że ich badania nie doprowadziły do całkowitego poznania i rozwiązania problemu, to stworzyli podwaliny nowoczesnego, teoretycznego podejścia do analizowania i zrozumienia zjawiska nacjonalizmu. W swoim pierwszym eseju What is nationalism? (Czym jest nacjonalizm? $\left.^{1}\right)$ Hayes napisał, że nacjonalizm jest to „stan umysłu członków narodu, być może mającego już państwo narodowe, stan umysłu, według którego wierność ideałowi państwa narodowego lub takiemu państwu istniejącemu faktycznie jest wyższa niż wszystkie inne zobowiązania, a jego częściami integralnymi są duma $\mathrm{z}$ własnej narodowości oraz wiara w jej wrodzoną doskonałość i «misję»"2. Należy przy toczyć również jego słowa: „nacjonalizm stał się dla ogromnej liczby osób prawdziwą religią, zdolną wzbudzać głębokie uczucie, które jest w gruncie rzeczy religijne. Przyjmując, że ludzie mają z natury «zmysł religijny», który jest tak głęboko zakorzeniony, że musi się przejawiać w taki czy inny sposób. Zinstytucjonalizowana religia stopniowo traci swój potencjał, a «masy» coraz bardziej przyciąga «wiara w państwo narodowe i jego kult»"3. Hayes uważał, że „nacjonalizm, jak każda inna religia, pełni w dużej mierze funkcję społeczną oraz że jego główne obrzędy i rytuały publiczne dokonuje się w imię całej społeczności i dla jej zbawienia"4. Hayes określił również pięcioelementową typologię odmian nacjonalizmu: humanitarny - ten, który był nieuchronnym krokiem do postępu ludzkości; jakobiński - cechował się misjonarskim podejściem i nietolerancją rewolucjonistów francuskich; tradycyjny - w odpowiedzi na jakobiński, był wzbudzany przez myślicieli arystokratycznych, mający na celu powstrzymanie rewolucji, podkreślając tradycje historyczne, przywiązanie do symboli historycznych; liberalny5: „Między nacjonalizmem jakobińskim a tradycyjnym był nacjonalizm liberalny, jak i inne nacjonalizmy, narodził się w XVIII wieku.

\footnotetext{
Wszystkie terminy i nazwy wykorzystane w tekście - tłumaczenie Jędrzej Fostiak.

C. Hayes, Essays on Nationalism, Macmillan, New York 1926, s. 1. Ibidem.

4 P. Lawrence, Nacjonalizm. Historia i teoria, przeł. P.K. Frankowski. Warszawa 2007,
} s. 120 .

Ibidem. s. 121. 
Pojawił się w Anglii, państwie wiecznego kompromisu i wrażliwej samoświadomości narodowej, w umyśle Jeremiego Benthama, wyjątkowego talentu i profesjonalnego reformatora”. Hayes dodał także, że „każda narodowość powinna być jednostką polityczną, z niezależnym rządem konstytucyjnym, który położy kres despotyzmowi, arystokracji i wpływowi Kościoła oraz zapewni każdemu obywatelowi najszerszy możliwy zakres wolności osobistej” i całościowy - najgroźniejszy według Hayesa - ,agresywny, ekspansjonistyczny, cechujący się wyłącznym dążeniem do polityki narodowej, kategorycznym utrzymywaniem narodowej integralności oraz ciągłym wzrostem potęgi narodowej"7, była to nowa forma nacjonalizmu, nastawiona wrogo do internacjonalizmu głoszonego przez zwolenników nacjonalizmu humanitarnego czy liberalnego, zakładała, że naród jest celem samym w sobie, a nie etapem przejściowym w rozwoju ludzkości ${ }^{8}$.

Hans Kohn z kolei, pisał w jednej ze swoich najsłynniejszych prac, że „współczesny nacjonalizm sięga najwyżej drugiej połowy XVII wieku, a narodowości istniały zawsze, jako «materiał etnograficzny», ale nacjonalizm jako wszechobecna świadomość grupowa powstał w czasach rewolucji francuskiej"9. Ponadto dopiero w XIX wieku zaczęto uznawać państwo narodowe za ,idealną i najdoskonalszą formę organizacji politycznej, naród za źródło wszelkiej prawdziwej pomyślności kulturowej i gospodarczej"10. Według Kohna ideologia ta wywodzi się od Żydów i Greków, ale stopniowo została zastąpiona przez „uniwersalistyczny” ogląd świata ${ }^{11}$. Autor wskazuje na Olivera Cromwella jako pierwszego przedstawiciela nowoczesnego nacjonalizmu, który „nosił wciąż religijne szaty, ale był w pełni świadom ich implikacji politycznych”. Kohn uważał też, że to wczesne połączenie z religią wyjaśnia szczególnie nieskomplikowaną naturę poczucia narodowego w Anglii ${ }^{12}$ : „W rewolucji angielskiej akceptowano idee Starego Testamentu, przymierza, narodu wybranego, mesjańskiego królestwa i stosowano je w Anglii. Nowa świadomość narodowa Anglii jako pobożnego ludu przeniknęła cały naród, a Biblię czytali wszyscy, nie tylko intelektualiści. Anglia stała się pierwszym narodem w nowoczesnym rozumieniu nacjonalizmu.

s. 120.

C. Hayes, The Historical Evolution of Modern Nationalism, Macmillan, New York 1931.

P. Lawrence, Nacjonalizm..., s. 123.

Ibidem.

9 H. Kohn, Nationalism and Imperialism In the Hitler East, Routledge, Londyn 1932, s. 388 .

10 P. Lawrence, Nacjonalizm..., s. 126.

11 Ibidem.

12 Ibidem. 
W rezultacie nacjonalizm nigdy nie popadł w konflikt z religią i zakorzenił się w angielskim charakterze tak, że stał się prosty i „naturalny”’3.

Jak w odniesieniu do powyższego plasuje się kwestia szkockiego nacjonalizmu - jakim jest nacjonalizmem humanitarnym, liberalnym czy może całkowitym? Odwołując się do Hayesa jest to raczej nacjonalizm liberalny, który stale ulega modyfikacjom ze względu na otoczenie zewnętrzne i wydarzenia wewnętrzne mające miejsce na Wyspach Brytyjskich, Europie i samej Szkocji.

\section{Szkoccy narodowcy}

Scottish National Party (SNP) - Szkocka Partia Narodowa - tak brzmi nazwa tej organizacji, w poprawnym, polskim tłumaczeniu. Bardzo często spotyka się obecnie określenie nacjonalistyczna Partia Szkocji, prawdopodobnie ze względu na błędne tłumaczenie. Należy zatem wyjaśnić różnicę w tłumaczeniu, postrzeganiu i określaniu terminu national. W języku angielskim słowo national oznacza narodowy (państwowy), a słowo nationalism - nacjonalizm, co ma głównie negatywne konotacje, w odróżnieniu od terminu „narodowy”. Scottish National Party to dlatego Szkocka Partia Narodowa, a nie nacjonalistyczna, co powoduje, że analizujemy ją z innego punktu widzenia, bez zabarwienia negatywnego i innych dodatkowych implikacji.

Organizacja ta głosi hasło: Together we can make Scotland better (Razem możemy zmienić Szkocję na lepsze) ${ }^{14}$. Z informacji, jakie można uzyskać u źródła wynika, że jest to partia socjaldemokratyczna skupiona wokół kwestii secesji Szkocji od Królestwa Brytyjskiego i że dążenia oraz działania trwają od ponad siedmiu dekad. Jej początki sięgające lat 20. i 30. XX wieku, kiedy to powstała w 1921 roku Szkocka Narodowa Liga (Scots National League) oraz stworzone w 1927 roku Stowarzyszenie Szkockich Nacjonalistów z Uniwersytetu w Glasgow (Glasgow University Scottish Nationalist Association) łącznie wraz ze Szkockim Ruchem Narodowym (Scottish National Movement) stworzyły w 1928 roku Narodową Partię Szkocji (National Party of Scotland), która w 1934 roku połączyła się ze Szkocką Partią (Scottish Party) i stała się w reszcie Szkocką Partią Narodową (SNP) ${ }^{15}$. W 1999 roku na ceremonii rozpoczęcia obrad Szkockiego Parlamentu Winnie Ewing, (zaszczyt otwarcia obrad przypada

14 Oficjalna strona internetowa Szkockiej Partii Narodowej, www.snp.org (10.05.2014).

15 www.snp.org/about-us (20.05.2014). 
najstarszemu członkowi) powiedziała: „Obrady Parlamentu Szkockiego odroczone w dniu 25 Marca 1707 r. są zwołane ponownie ${ }^{16 " . ~ E w i n g ~ o d w o ł y w a ł a ~ s i e ̨ ~}$ do 1707 roku, kiedy to ustawa o unii otrzymała królewską blokadę. Wybory do Parlamentu Szkockiego prawie trzy wieki później pokazały nowy rozdział i nowy start dla Szkocji. Oczekiwania były bardzo wysokie odnośnie do decentralizacji, która miała przynieść znaczące zmiany i członkowie Parlamentu byli zadowoleni z utrzymania tymczasowych posad. Nadszedł czas i w 2007 roku nastąpił przełom dla SNP - po wyborach do Parlamentu i samorządu terytorialnego. Po ośmiu latach niskich ambicji (politycznych) oraz słabych osiągnięciach liberalnych demokratów, Szkoci byli gotowi na świeże myślenie i nowe podejście, a SNP zapewniało oba te aspekty ${ }^{17}$.

Pozytywna kampania SNP oparta była na kluczowym twierdzeniu, że Szkocja może być bardziej skuteczna i może odnieść większe sukcesy w poszczególnych dziedzinach dotyczących: podstawowej opieki zdrowotnej zachowanej na poziomie lokalnym; większego wsparcia dla małych przedsiębiorstw; bezpieczniejszych społeczności; niższego i bardziej sprawiedliwego podatku, dzięki czemu więcej pieniędzy zostanie w kieszeniach obywateli na koniec każdego miesiąca. Partia miała też korzyści z nowego narzędzia, a mianowicie głosowania za pośrednictwem internetu (online election), które pozwoliły wyborcom znaleźć odpowiednich kandydatów SNP w zaciszu własnych domów ${ }^{18}$. Gdy głosy zostały ostatecznie zliczone, SNP okazała się największą partią w liczbie oddanych głosów i liczby posłów. SNP miał 32,9\% głosów - najlepszy wynik w historii partii - w porównaniu do Labourzystów 32,2\% i 47 posłów w stosunku do Labourzystów 46. SNP wygrała wybory i utworzyła rząd ${ }^{19}$. Po wyborach, lider SNP Alex Salmond obiecał prowadzić Szkocję z pokorą i pasją i zawsze w imię interesu narodowego, a nie na korzyść partii, cytując słowa szkockiego pisarza Alasdaira Graya „Pracuj, jakbyś mieszkał w pierwszych dniach lepszego państwa" ${ }^{20}$.

Wybory parlamentarne w 2011 roku były punktem zwrotnym w historii szkockiej polityki i Parlamentu Szkockiego. Po niezwykle dobrej kampanii wyborczej, SNP zdobył bezwzględną większość w Parlamencie Szkockim 69 miejsc - bezwzględną większość w Parlamencie Szkockim. Wyczyn bardzo znaczący,

\footnotetext{
16 Ibidem.

17 www.snp.org/about-us (20.05.2014).

18 Ibidem.

19 Ibidem.

20 Ibidem.
} 
zważywszy, że system wyborczy miał charakter proporcjonalny i w związku z tym najczęściej po wyborach jednopartyjna większość rządowa jest rzadkością.. Po historycznym zwycięstwie, przywódca SNP Alex Salmond zapowiedział, że zostanie przeprowadzone referendum w sprawie niepodległości Szkocji w ciągu 5 lat. Powiedział również, że SNP miała „większość mandatów, ale nie monopolu na mądrość". Dodał, że SNP będzie niosło nadzieje narodu (szkockiego) i sprawi, że naród będzie z tego dumny ${ }^{21}$.

Gdy podliczono wszystkie mandaty, wyniki była następujące: SNP - 69, Labourzyści - 37, Torysi - 15, Liberalni Demokraci - 5 i pozostali - 3. Alex Salmond powiedział wówczas: „Będę rządzić dla wszystkich szkockich ambicji i dla wszystkich ludzi, którzy wyobrażają sobie, uważają, że możemy żyć w lepszym kraju. (...) Ta partia, Szkocka partia, narodowa partia, niesie Waszą nadzieję. Będziemy nieść ją ostrożnie i uczynimy naród dumny ${ }^{22 "}$.

\section{Program SNP}

Organizacja SNP, poza marketingowymi sloganami i populistycznymi jakby się mogło zdawać - hasłami, dostarczała również szerokiej wiedzy i wskazywała konkretne rozwiązania społeczeństwu: „My wiemy jak będzie wyglądała niepodległa Szkocja i co to dla Was oznacza". Rząd Szkocki opracował White Paper (przewodnik wraz z całą serią załączników i swoistych instruktaży), gdzie wskazano poszczególne sektory życia publicznego i wyjaśniono jakie zajdą w nich zmiany - po pozytywnym wyniku referendum ${ }^{23}$.

Propozycje zmian dla rodzin nakreślane były w następujący sposób: „Nasze finanse publiczne są w znacznie lepszej kondycji niż Zjednoczonego Królestwa. Mamy mocną pozycję na przyszłość i mamy:

- Duże oszczędności 600 milionów funtów, ponieważ nie musimy więcej płacić za takie rzeczy jak broń nuklearna, czy politycy w Westminster pieniędzy, które możemy zainwestować w istotne sprawy takie jak nowe miejsca pracy.

- Możemy zaoszczędzić część naszej zdrowotnej energii w Funduszu Deszczowy Dzień, który daje nam duże finansowe bezpieczeństwo, dzisiaj i dla przyszłych pokoleń.

21 Ibidem.

22 www.snp.org/about-us (20.05.2014).

23 Oficjalna strona internetowa organizacji prowadzącej kampanię na rzecz niepodległości Szkocji, www.yesscotland.net/news/what-independent-scotland-can-mean-you (10.05.2014). 
- Polityka ekonomiczna zaprojektowana dla Szkocji abyśmy mogli lepiej wykorzystać nasze surowce i talenty do tworzenia więcej możliwości" ${ }^{24}$. Partia odpowiadała również na pytanie: Jak powinna wyglądać niepodległa Szkocja: „Mamy najbardziej szczegółowy plan, jaki kiedykolwiek, jakiekolwiek państwo przygotowało wkraczając w niepodległość. Jest oparty na konsultacjach dostarczanych przez szkockich i międzynarodowych ekspertów, włączając w to dwóch laureatów Nagrody Nobla. Przewiduje on:

- funt jako szkocka waluta, co pozwoli uniknąć przewalutowań przy kredytach,

- wyjście z systemu Westminster, który to nie działa na rzecz Szkocji i uszczupla standardy życia społeczeństwa całego kraju,

- Szkocki Parlament otrzyma nowe siły nad gospodarką i społeczeństwem co spowoduje, że życie stanie się lepsze dla obywateli’"25.

Jakie będą korzyści z niepodległości dla obywatela? „Młode rodziny szczególnie powinny otrzymywać więcej pomocy od państwa za pracę, jaką wkładają w prawidłowy rozwój, aby życie ich dzieci było lepsze. W szkockiej przyszłości możemy sami wybierać różne możliwości jeśli chcemy:

- Możemy dostarczyć transformacyjny wzrost w opiece nad dziećmi podwajając blisko darmową edukację przedszkolną dla trzy i cztero-latków. Zostanie to rozszerzone również na wszystkie jedno i dwulatki.

- Będziemy mogli udzielić Wam [małżeństwom z dziećmi - dop. J.F.] zniżek w wysokości 5 procent na rachunki za energię elektryczną.

- Możemy wykonać pierwsze kroki do bardziej sprawiedliwej Szkocji z rocznym kosztem życia i zwiększeniu minimalnego wynagrodzenia, podstawowej stawki podatku, ulgi podatkowej, świadczeń socjalnych"26.

Odniesiono się również do kwestii finansowych i podatkowych: „Szkocka przyszłość będzie w szkockich rękach i to oznacza, że możemy zrobić więcej dla ludzi zaczynających dorosłe życie i karierę. Będziemy mieli nasz własny Rząd ze wszystkimi atrybutami i narzędziami, aby zadbać o interes ludzi tego kraju. Wybory będą dokonywane w Szkocji:

- Możemy być pewni, że zatrzymacie więcej ze swojej ciężko zarobionej gotówki mimo podatków, ulg podatkowych oraz inflacji.

${ }^{24}$ www.yesscotland.net/sites/default/files/resources/documents/case_study_-_young_people.pdf (25.05.2014).

25 Ibidem.

26 Ibidem. 
- Będziemy mogli pomóc zmniejszyć presję finansową udzielając zniżki na rachunki energii elektrycznej 5 procent.

- Powołamy Komisję Sprawiedliwego Wynagrodzenia (Fair Wage Commision), aby zapewnić ludziom najsłabiej zarabiającym zarobki na takim poziomie, aby mogli zarobić na koszty utrzymania rosnące $\mathrm{z}$ roku na rok"27.

W programie można było znaleźć także propozycje zmian dla nastolatków i dwudziestolatków: „Będziemy mogli zabezpieczyć ważne polityki m.in. darmowa edukacja wyższa, ponieważ będziemy sami zarządzali tym, co zarobimy i tym, co wydamy.

- Niepodległość będzie ekscytującym i historycznym wydarzeniem dla Szkocji, który wyzwoli okres wielkiej kreatywnej energii. Oczy Świata będą skierowane na nas i będziemy mieli okazję przedefiniować, kim Jesteśmy jako naród.

- Możemy uczynić większym nasz olbrzymi potencjał energii odnawialnej... zwiększyć ilość miejsc pracy jako lider światowy w technologii morskiej energii wiatrowej i technologii pływowej"28.

Program odnosił się również do ludności wiejskiej w następujący sposób: „Szkocja posiada bogate złoża surowców naturalnych. Możemy zrobić jeszcze wiele, aby zwiększyć gospodarczy potencjał Szkocji z korzyściami dla ludzi tutaj żyjących. Z odpowiednim zaangażowaniem i wysiłkiem możemy zrealizować wszystkie cele:

- Zniżka na energię elektryczną 5\%.

- Oddamy Pocztę z powrotem pod państwowy zarząd i obniżymy wysokie koszty przesyłek w wiejskich obszarach (...)

- Możemy wykorzystać naszą sieć dystrybucyjną za granicą na promowanie Szkocji i głównych gałęzi przemysłu na całym świecie, przynosząc nowe miejsca pracy poprzez zwiększenie turystyki i zdobywanie nowych rynków zbytu dla naszego sektora spożywczego i napojów”29.

W dokumencie zapisano także propozycje dla małych firm: „Obie strony debaty zgadzają się w kwestii niezależności teraz, że Szkocja może być naprawdę niezależnym krajem. Nasze finanse publiczne są zdrowsze niż Wielkiej Brytanii,

27 www.yesscotland.net/sites/default/files/resources/documents/case_study_-_young_people.pdf (25.05.2014).

28 www.yesscotland.net/sites/default/files/resources/documents/case_study_teens_and_ twenties.pdf (25.05.2014).

29 www.yesscotland.net/sites/default/files/resources/documents/rural_scotland_case_study.pdf (26.05.2014). 
obecnie i gdy chcemy uniezależnić się w 2016 posiadamy bardzo dobrą pozycję i przesłanki ku temu:

- Umiejętność projektowania polityki i ulg podatkowych zwiększy konkurencyjność i wsparcie dla szkockich firm w Szkocji, w przeciwieństwie do coraz bardziej oddalającej się polityki centrycznej Londynu.

- Możliwość upewnienia się, że szkocki system podatkowy jest prostszy, w celu zmniejszenia kosztów przestrzegania przepisów/prowadzenia działalności dla małych przedsiębiorstw w szczególności.

- Będąc częścią UE i wspólnego rynku z ponad 500 milionami ludzi, korzystających z tych samych praw w handlu i dostępu jak dziś i za granicą w sieci zaprojektowanej, aby skutecznie promować Szkocję na światowych rynkach. Szkockie podatki przeznaczane obecnie na funkcje i usługi w Londynie i południowym wschodzie [Wlk. Brytanii - dop. J.F.], a nie na finansowanie tych usług w Szkocji, przynosząc nowe miejsca pracy i dostarczania impulsu gospodarczego oraz nowych możliwości dla rozwoju małych przedsiębiorstw.

- Niezależna Szkocja będzie mogła zrobić więcej, aby uczynić więcej atutów gospodarczych dla Szkocji. Będziemy mogli zaprojektować naszą politykę sami w Szkocji, dla Szkocji, z krótszymi liniami podejmowania decyzji, z większą szybkością i elastycznością i z determinacją, aby dać Szkocji «krawędź» gospodarczą [silną gospodarkę - dop. J.F.].

- Z nowymi uprawnieniami w naszej gospodarce i systemie podatkowym, możemy: dostarczyć nową pomoc dla małych przedsiębiorstw poprzez niższe krajowe koszty ubezpieczenia, co ułatwi tworzenie nowych miejsc pracy. Będziemy mogli zmniejszyć o 50\% koszty, jakie ponoszą podróżni podróżujący samolotami, aby jeszcze bardziej zachęcić do bezpośrednich lotów do Szkocji i zwiększyć nasz ważny sektor turystyczny.

- Kontynuowanie ulepszania systemu ulg podatkowych dla firm na Wyspach i sygnalizować przyszłe redukcje podatku dochodowego od osób prawnych, w celu przeciwdziałania działalności grawitacyjnej i przyciągnąc (firmy, biznes - przyp. autor) z Londynu"30.

Według planu SNP: ,przyszły brytyjski monarcha dalej byłby formalnie głową niepodległej Szkocji, tak samo jak jest nią dla np. Kanady lub Australii. Szkocja zachowałaby również brytyjską walutę. Rząd w Edynburgu natomiast sam pobierałby podatki i prowadził własną politykę zagraniczną. Stworzono

30 www.yesscotland.net/sites/default/files/resources/documents/case_study___small_business.pdf (25.05.2014). 
by, także narodowe siły obronne, w tym wojska lądowe, powietrzne i morskie. Brytyjskie łodzie podwodne o napędzie atomowym musiałyby odpłynąć ze szkockich baz. A to właśnie w Scapa Flow na Orkadach mieści się główna baza brytyjskiej Royal Navy. Salmond podkreśla, że po oderwaniu Szkocja nie podniosłaby podatków, ponieważ Szkoci nie musieliby dłużej płacić za brytyjski arsenał nuklearny, a pieniędzy państwu dostarczałyby bogate złoża ropy i gazu na Morzu Północnym. Szkocja wzorem Norwegii utworzyłaby również fundusz, na który spływałyby petrofunty [środki pochodzące z wydobycia oraz sprzedaży paliw]. Szkocja zostałaby również w Unii Europejskiej - chociaż Bruksela jeszcze nie odniosła się do niepodległości Edynburga, a niektóre państwa Wspólnoty, np. Hiszpania, której częścią jest Katalonia, mogłyby nie być specjalnie za takim rozwiązaniem. Co ciekawe szkic Salmonda jasno formułuje prawo niepodległych Szkotów do oglądania swoich ulubionych filmów i seriali z brytyjskiej stacji $\mathrm{BBC}$, chociaż pod nową nazwą SBC - jak nie trudno zgadnąć to skrót od Scottish Broadcasting Service. Widać, że Salmond walczy o szeroki elektorat. A ma o co. Niepodległość popiera 25 procent mieszkańców Szkocji” ${ }^{31}$. Partia SNP, jak sama mówiła o sobie, odnosi się do wszystkich obywateli i dla każdego ma coś w zanadrzu, coś - czego Szkoci dotąd nie dostawali lub nie wiedzą, że to dostają.

Jednym z największych problemów w Szkocji jest obecnie napływ dużej liczby imigrantów (oraz związane z tym i odczuwalne straty ponoszone na rzecz „,nowych”). Od roku 2001 (m.in. z powodu wejścia Polski do UE) w Szkocji nastąpił swoisty najazd i okupacja socjalno-społeczno-ekonomiczna. Wiele osób, które przybyły do Szkocji często nie pracuje i jest na zasiłkach lub świadczeniach społecznych, za które płacą przede wszystkim ci, którzy uczciwie pracują i płacą podatki. Szkoci, znani ze swej skrupulatności oraz oszczędzania i negatywnego stosunku do trwonienia pieniędzy, są na etapie, że tak przeprowadzana wspólnotowość i otwieranie rynku pracy nie jest dla nich korzystna i dlatego mówią odważnie: „Chcemy sami decydować o nas samych”. W kraju tak tradycyjnym, gdzie świadomość społeczna jest na bardzo wysokim poziomie, ciężko jest nie dostrzegać tych negatywnych zjawisk. Szkocja jest kolejnym krajem, obok krajów skandynawskich, gdzie napływ mniejszości oraz tzw. taniej siły roboczej ze wschodu Europy, Afryki czy Azji sprawia, że nastroje społeczne oraz opinia publiczna zmienia swoje nastawienie do problemu imigrantów. „Jeżeli imigranci przyjeżdżają i pracują to wtedy jest dobrze pod warunkiem, że obywatele szkoccy mają pracę w pierwszej kolejności, ale gdy imigranci przybywający otrzymują,

31 M. Wachnicki, O co walczq Szkoci, „Newsweek.pl” 2013, www.swiat.newsweek.pl/ niepodleglosc-szkocji-referendum-szkocja-newsweek pl,artykuly,275701,1.html (25.05.2014). 
od razu zasiłki od Królowej Brytyjskiej, «tak po porostu, za nic, bez wymogu pracy itd. To nie jest fair»" ${ }^{\prime 32}$. Budzi to gorące emocje, które widoczne i słyszalne są przede wszystkim na ulicach Edynburga, Glasgow i innych miast i miasteczek przepięknej Szkocji, a których nie pokazuje się w serwisach informacyjnych BBC czy CNN albo TVN, Polsat lub TVP.

\section{Referendum}

W dniu referendum Szkoci zagłosowali za pozostaniem i nieodłączeniem się od Korony Brytyjskiej. Uprawnionych do głosowania było ok $4 \mathrm{mln}$ ludzi zamieszkujących Szkocję, z czego ok 30 tys. Polaków z prawami do głosowania. Przewidywana była rekordowa wysoka frekwencja ${ }^{33}$. Po długim i pełnym napięcia dniu, w końcu nastąpiło przeliczenie głosów ze wszystkich komisji wyborczych w 32 okręgach, wyniki głosowania wyglądały następująco: 55,3\% Szkotów opowiedziało się przeciwko wystąpieniu z Wielkiej Brytanii. Oznacza to, że na TAK zagłosowało $1 \mathrm{mln} 617989$ wyborców. Przeciwko niepodległości zagłosowało więc nieco ponad 55\%. wyborców, czyli 2 mln 001926 głosujących. Więcej niż 50\% poparcia idea niepodległości zyskała tylko w czterech z 32 okręgów: Dunded (57,35\%), West Dunbartonshire (53,96\%), Glasgow $(53,49 \%)$ i North Lanarkshire (51,07\%). Frekwencja wyniosła 84,6\%. Wyniki referendum zapewniają Wielkiej Brytanii utrzymanie znacznej części terytorium, złóż ropy oraz zlokalizowanych w Szkocji baz arsenału nuklearnego. Decyzja Szkotów, jak pisze Associated Press, daje też Wielkiej Brytanii szansę uniknięcia niestabilności finansowej, prognozowanej przez część ekspertów w razie secesji Szkocji oraz utrzymanie siły brytyjskiego głosu w instytucjach międzynarodowych, w tym w $U^{34}$. Jak się okazało, społeczeństwo szkockie przemówiło inaczej. Z perspektywy czasu oraz po analizie wielu źródeł, można się było tego spodziewać. Na pewno bardzo rozczarowało wielu zwolenników wolności i niepodległości, na rzecz przemyślanego i wykalkulowanego rachunku finansowo-gospodarczego, jakim niewątpliwie okazała się jedność z Królestwem Brytyjskim na dotychczasowych zasadach. Globalna sytuacja finansowa oraz konflikty zbrojne w Europie,

32 Rozmowa autora przeprowadzona w Scarborough Royal Hotel z jednym ze szkockich obywateli w dniu 27.08.2012

33 M. Rybarczyk, Sądny dzień Królestwa w liczbach, "Newsweek.pl"2013, www.swiat.newsweek.pl/referendum-w-szkocji-2014-niepodleglosc-szkotow-newsweek-pl,artykuly,347934,1. html (18.09.2014).

34 Mtom, Sprawdź jak głosowali Szkoci, „Tvn24.pl” 2014, www.tvn24.pl/wiadomosci-ze -swiata,2/sprawdz-jak-glosowali-szkoci,469692.html (20.09.2014). 
mogły mieć swoje przełożenie na obawy większej części społeczeństwa Szkotów, co spowodowało, że nie zdecydowali się na tak rewolucyjne rozwiązanie - prawdopodobnie także nie był to znowu odpowiedni czas na samodzielność.

\section{Bibliografia}

Antoszewski Andrzej, Herbut Ryszard, Systemy polityczne wspótczesnej Europy, Warszawa 2008.

Calhoun Craig, Nacjonalizm, Buckingham, Open University Press 2002, polskie wydanie: Nacjonalizm, przeł. Bohdan Piasecki, Warszawa 2007.

Czapiewski Tomasz, Ksztaltowanie się systemu politycznego Szkocji, 2013.

Garner Robert, Kelly Richard, British Political Parties Today, Manchester University Press, 1998.

Harvie Christopher, Scotland and Nationalism: Scottish Society and Politics, 1707to the Present, Psychology Press, 2004.

Hassan Gerry, The Modern SNP: From Protest to Power, Edinburgh University Press, 2009.

Herbut Ryszard, Teoria i praktyka funkcjonowania partii politycznych, Wrocław 2002.

Kohn Hans, Nationalism and Imperialism In the Hitler East, Routledge, Londyn 1932.

Lawrence Paul, Nacjonalizm. Histiory and Theory, polskie wydanie: Nacjonalizm. Historia i teoria, przeł. Paweł K. Frankowski, Warszawa 2007.

Le Bon Gustav, La Psychologie des Foules, Felix Alcan, Paryż 1905.

Le Bon Gustav, Les Lois psychologiques de l'evolution des Peoples, Felix Alcan, Paryż 1895.

Lynch Peter, SNP: The History of the Scottish National Party, Welsh Academic Press 2002.

Pillsbury Walter Bowe, The Psychology of Nationality and Internationalism, Appleton, New York 1919.

Ideologie, doktryny i ruchy narodowe. Wybrane problemy, red. S. Stępień, Lublin 2006. Wspótczesne systemy polityczne, red. Marek Żmigrodzki, Bożena Dziemidok-Olszewska, Warszawa 2013. 


\section{Źródla internetowe:}

Mtom, Sprawdź jak głosowali Szkoci, „Tvn24.pl” 2014, PAP, www.tvn24.pl/wiadomosci -ze-swiata,2/sprawdz-jak-glosowali-szkoci,469692.html.

Rybarczyk Marek, Rybarczyk: Sądny dzień Królestwa w liczbach, „Newsweek.pl” 2014, www.swiat.newsweek.pl/referendum-w-szkocji-2014-niepodleglosc-szkotow-newsweek-pl,artykuly,347934,1.html.

Wachnicki Michał, O co walcza Szkoci, „Newsweek.pl” 2013, www.swiat.newsweek.pl/ niepodleglosc-szkocji-referendum-szkocja-newsweek pl,artykuly,275701,1.html.

www.bbc.com/news/uk-scotland-scotland-politics-25088251.

www.polscott24.com/szkocka-partia-narodowa.

www.snp.org.

www.snp.org/about-us.

www.yesscotland.net/news/what-independent-scotland-can-mean-you.

www.yesscotland.net/sites/default/files/resources/documents/rural_scotland_case_study.pdf.

www.yesscotland.net/sites/default/files/resources/documents/case_study_-_small_business.pdf. www.yesscotland.net/sites/default/files/resources/documents/case_study_teens_and_twenties.pdf. www.yesscotland.net/sites/default/files/resources/documents/case_study_-_young_people.pdf.

\section{Streszczenie}

Autor w krótkim zarysie przedstawił kwestię odmiennego podejścia do narodowości w dążeniu do uniezależnienia się Szkocji spod panowania Wielkiej Brytanii. Próbuje też odróżnić nacjonalizm od ruchu narodowego, który jest postrzegany jako pozytywny, ale często utożsamiany z nacjonalizmem, który ma negatywne znaczenie w obiegowym użyciu i powszechnym zastosowaniu. Analizuje program Narodowej Partii Szkocji, która doprowadziła do przeprowadzenia referendum niepodległościowego, po raz pierwszy w historii obu tych państw i utożsamiała dążenie do niepodległości Szkotów od ponad 300 lat.

Słowa kluczowe: nacjonalizm, narodowość, Szkocja, niepodległość, referendum, Wielka Brytania, secesja, społeczeństwo, ruch społeczny 


\title{
SCOTTISH NATIONALISTS AND THE QUESTION OF SECESSION FROM THE UNITED KINGDOM
}

\begin{abstract}
Summary
The author intends to present a brief outline a different approach to the question of nationalities in the quest for independence of Scotland from the dominion of Great Britain. It also tries to distinguish between nationalism of the national movement, which is seen as a positive, but often identified with nationalism, which has a negative meaning in the common use and common use. Examine the program of the National Party of Scotland, which led to a referendum on independence, for the first time in the history of the two countries and to equate the desire for independence of Scots for over 300 years.
\end{abstract}

Keywords: Nationalism, nationality, Scotland, independence, referendum, United Kingdom, separation, society, social movement 